\title{
Revogação dos atos administrativos
}

\author{
Fernando Henrique Mendes de Almeida \\ Livre docente de Direito Administrativo na Faculdade de \\ Direito da Universidade de São Paulo.
}

\section{Observações preliminares}

1 - A primeira dificuldade, que se nos apresenta, relativamente à questão da revogação dos atos administrativos, é a que se prende à conceituação do instituto da revogação. Com efeito, de início, pode parecer fácil determinar o conteúdo ideológico da expressão em exame. Bastará, assim, lembrar o que ocorre no Direito Privado, e, a seguir, concluir: a revogação pressupõe necessàriamente o mesmo agente do ato em que ela recai. Entretanto, não haverá aí uma noção sequer, porquanto não se esclarece, em tal pensamento, a causa determinante do instituto, nem o fim a que se destina o exercício da revogação.

Em verdade, a questão, conquanto de preliminar interêsse, não só é importantíssima para a compreensão do tema em foco, mas também não apresenta as facilidades que, à primeira vista, supomos haja na sua substância.

2 - Realmente. Se consagrarmos nossa atenção a um balanço acêrca de quanto, de essencial, os escritores disseram, no Direito Administrativo, a propósito da revogação dos atos administrativos, chegaremos à conclusão de que a questão, apontada como preliminar, já de sí é um mundo. Procurando, pois, sintetizar o que há, como matéria para um tal balanço, devemos, desde logo, deixar notado que não se pode conceituar a revogação dos atos administrativos, sem, antes, distinguir tal instituto, de outro que, por 
ser dêle convizinho, é, amiúde, objeto de confusões. Referimo-nos, como é bem de ver, à anulação.

3 - Quatro tendências assinala Codacci-Pisanelli, na obra "L'annullamento degli atti amministrativi", no que respeita às distinções propostas por diversos autores, que êle cita. Vejamos como se apresentam os critérios sugeridos.

4 - Numa primeira tendência, que é de Kormann e Alessi, a distinção é realizada à base de elemento subjetivo. A anulação - dizem tais autores - pressupõe ato de outra autoridade, de outro agente, enfim, que não daquêle em que recai; de revés, a revogação pressupõe ato do mesmo agente realizador de ato anterior, no qual ela recai.

O critério não é destituído de alguma verdade. Entretanto, não há negar que êle exagera notas de idéias que só incidentemente poderiam ser invocadas. E a razão do que afirmamos está aqui: normalmente, para que ocorra a idéia de revogação, não é necessário que o agente da revogação e o do ato em que ela incide se identifiquem num só agente, mas basta que o revogador seja do mesmo Poder do Estado, do qual emanou o ato a que se refere a revogação. Esta observação deflui, particularmente, da circunstância de, em matéria de recursos administrativos, haver três espécies: a da oposição, que é o recurso administrativo destinado a impugnar o ato ante o próprio agente de que emanou (o que pressupõe o mesmo órgão, agente do ato revogado); a do recurso hierárquico próprio, que é destinado à impugnação do ato, pela revogação a cargo do superior hierárquico imediato; a do recurso hierárquico impróprio, o qual é destinado à impugnação do ato, pela revogação a cargo de superior hierárquico mediato.

Por outro lado, se bem que, normalmente, a revogação pressuponha o mesmo Poder, de que emanou, e não necessàriamente o mesmo agente do ato em que recai, pode ela provir de outro Poder. Servem de exemplos, nos períodos de governos de fato, os decretos (atos do Executivo) que 
revogam leis, feitas pelo Legislativo e, ainda, o mesmo fenômeno, em governos de direito, desde que admitam não ser a lei a única fonte primária da norma jurídica. Os exemplos abundam, ainda, nos escritores que estudaram a categoria dos decretos-leis (no sentido adequado desta expressão, i.é, ligado à coexistência de Parlamento) entre os quais lembramos: Scialoja, Zanobini, Waline, Balochowsky-Pétit, e muitos outros.

5 - O segundo critério, que é de Georges Jellinek, estabelece a distinção pelo efeito. A anulação atinge o ato, a partir do momento, em que é exercitada, i.é, ela é "ex-nunc"; de revés, a revogação retroage; atinge os efeitos anteriores à sua ocorrência, i.é, é "ex-tunc"

Muito de exato há no que se leu até aqui. Apenas não pode embasar distinções. Que a lanulação é "ex-nunc", ninguém pode duvidar, pois, está na própria palavra que só se pode "anular" o que antes não era nulo e, ademais, é sabido que $o$ ato anulável se distingue do válido nisto: aquêle produz efeitos jurídicos, suprimiveis; êste produz efeitos jurídicos insuprimíveis. Logo, se a anulação se abate sôbre $o$ ato anulável, tem de, forçosamente, ser "exnunc" Quanto à revogação, pode ser "ex-tunc", ou "ex-nunc", como o demonstram leis retroativas e não retroativas.

6 - O terceiro critério é, ainda, objetivo. Vêmo-lo diluido por obras de muitos escritores italianos, como Ranelletti ("Le guarantigie della giustizia nella pubb. am", e "Teoria degli atti am. especiali") Zanobini ("Corso", I) e outros. Se o ato que retira outro se inspira em razões presas à conveniência, ou à oportunidade da A.P., i.é, o mérito, o de que se trata é de revogação; se considera a falta de legitimidade, o de que se trata é de anulação.

Também há um pouco de verdade nesse critério, sem, porém, apresentar a serventia que se lhe quer dar, entre os seus adeptos. Anula-se um ato por vício de ilegitimidade, entendido nisto, apenas, a invalidade relativa, i.é, a 
que induz efeitos jurídicos suprimíveis, purgáveis, aliás, "tractu temporis", para usar uma expressão das fontes. De-revés, sendo certo que a revogação pode considerar o mérito, nada impede, como se demonstrará, a seguir, que ela atinja o vício de ilegitimidade em gênero.

7 - $\mathrm{O}$ critério exato de distinguir a revogação e a anulação, dá-o Codacci-Pisanelli, na obra já citada, fundando-se na opinião de Ipsen, a cuja obra faz expressa remissão. A anulação recai e só pode recair em ato anulável; a revogação pode recair tanto em ato válido como inválido em gênero. $\mathrm{E}$ que iremos demonstrar imediatamente.

a) se o ato é válido, mas essencialmente revogável (E podemos lembrar, no $\mathrm{D}$. Privado, o mandato revogável e o testamento), pode a A.P. revogá-lo, a qualquer tempo, e, disto, é exemplo a Autorização; b) se o ato é válido, mas apenas acidentalmente revogável, pode ser revogado, enquanto ainda não é eficaz, i.é, não está a produzir efetivamente os efeitos para que, como válido, é idôneo (1); c) se o ato é anulável, i.é, suscetível de produzir efeitos jurídicos suprimíveis, por falta de eficácia (causa: eficácia "pendente conditione"), pode ser revogado, antes que, tornando-se eficaz, obrigue à anulação, ou convalesça "tractu temporis"; d) se o ato é nulo, pode ser revogado, o que decorre da simples aplicação do princípio lógico "ad majorem minus".

8 - Bem se vê, à vista do exposto, que, na hipótese da letra "a", a revogação deflui da própria natureza do ato de que vem a ser destinatária, o qual, como essencialmente revogável, não deixa dúvida, nem originária, nem sucessiva,

(1) Tanto no D. A. quanto no D. Civil há duas categorias de opiniões: De Ruggiero, citando copiosa bibliografia alemá, nas "Ist. di D. Civile", diz que "eficácia" e "validade" são sinônimos; Coviello, no "Manuale di D. Civile" diz, no entanto, que "eficácia" é a produção em ato e "validade" a produção em potência. Dêste pensar é, no D. A., Codacci-Pisanelli, a que nos filiamos. 
sôbre poder ser revogado a qualquer tempo. Quanto às hipóteses das letras " $b$ " $e$ "c" (ato válido acidentalmente revogável, mas ainda ineficaz, e ato anulável, ainda ineficaz), é, sem dúvida, o mérito que pode atuar como móbil da revogação; contudo, esta não se poderá exercitar, se o ato válido já é eficaz i.é, legítimo, porque eficaz e válido, i.é, a produzir já os efeitos para que é idôneo; nem se poderá exercitar, se o ato é relativamente válido anulável e já é eficaz.

9 - Estabelecido que a anulação atinge apenas atos anuláveis, bem como que a revogação atinge os válidos $\mathrm{e}$ os inválidos, podemos extremar os dois institutos.

A anulação de ato administrativo é o instituto pelo qual se retira da ordem jurídica o ato de invalidade relativa; a revogação de ato administrativo é o ato pelo qual se retira: a) o ato jurídico, ou ato administrativo "strictu senso" essencialmente revogável; b) o ato administrativo válido, mas ainda ineficaz; c) o ato administrativo relativamente inválido, mas ainda ineficaz; d) o ato nulo. A anulação atua na ordem jurídica; a revogação nesta, ou na ordem material.

\section{Exercício do poder revocatório específico}

10 - No que respeita aos atos administrativos, a revogação normalmente pressupõe o mesmo Poder de que emanou $o$ ato revogado. Assim, dizer que uma sentença revogou ato administrativo ilegítimo é confundir a anulação com a revogação. Mas, a anulação, que, como vimos, só se compreende quanto a atos anuláveis, nalguns países, onde a auto-impugnativa é ampla, pode ser nascida do próprio Poder, ou do próprio agente de que emanou o ato anulável. Dai a circunstância de a doutrina estrangeira associar a revogação (que é auto-impugnação com base na executoriedade e na presunção de legitimidade dos atos 
administrativos) à anulação (que, nos países, em que tal doutrina faz a dita associação é realizável também pelo Poder Executivo). Mas, convém ponderar e distinguir. Onde a ação rescisória tem função determinada, é, de todo em todo, impossível e inadmissível que o agente do ato anulável, ou o Poder, de que êle emanou, o anule. Pode êsse Poder, contudo, revogá-lo, se ainda não se lhe nota a eficácia, o que é bem diverso.

\section{Limites do poder revocatório}

11 - Do que se disse acima tiram-se as regras que podem transmitir prudência àqueles que, eventualmente, hajam de passar pelo ensejo de distinguir a auto-impugnação e a hetero impugnação. As regras são estas: a) não se pode revogar ato anulável que já seja eficaz, sem, com isto, determinar conseqüências desastrosas, inclusive para o erário público, nalguns casos; entretanto, pode-se anular o ato anulável já eficaz, se não está êle beneficiado ainda da prescrição, o que, entre nós, como já se disse acima, não pode ocorrer senão em conseqüência de julgado defluente da ação rescisória; b) pode-se, conseqüêntemente, revogar: a) ato válido essencialmente revogável; c) ato válido acidentalmente revogável, enquanto ainda ineficaz; d) ato nulo, isto é, o que "ad initio vitiosum est et tractu temporis convalescere non potest".

12 - Das regras sintetizadas no n. 11 acima tiram-se muitos comportamentos, que deverão ser os adotados, por aquêles que ante os atos administrativos, pensam que "revogar" e "anular" são ações que se podem confundir.

Com efeito, que a anulação, ainda quando dependente de ação rescisória, tem seu tempo hábil, é isto idéia que não é possível perder de vista. De sorte que se Tício, com as suas imperfeitas noções do "nulo" e do "anulável", propõe rescisória relativa a ato administrativo que a pres- 
crição já tenha purgado, incorre num risco e o vem a sofrer efetivamente: o de encontrar o ato, antes anulável, já transformado em ato válido, em razão do fato jurídico do tempo. Essa transformação precisamente consiste em: efeitos jurídicos, originàriamente tidos como suprimíveis, se virem a tornar insuprimíveis. Desta parte segue-se que a anulação, por via de ação rescisória, do ato administrativo, também, está sujeita ao princípio geral de que "dormientibus non succurrit ius".

13 - Também e, com maior razão, o exercício do poder revocatório tem fronteiras. Relativamente ao ato administrativo válido, mas essencialmente revogável, é ocioso notar que pode êle ser revogado a qualquer tempo, não havendo têrmo final, nem têrmo inicial para que a revogação sôbre êle se exerça.

No caso da Autorização, que, além do mais, é ato discricionário, dúvida alguma pode padecer o que se disse acima. Ela se revoga, ainda que conte 20 anos, ou 30 , ou 40, a partir da data em que começou a operar o seu caráter removedor. Verificada a revogação, a atividade, antes autorizada ao administrado, passa automàticamente à posição de ilícita, se exercida, a despeito da revogação. Mas, se a revogação diz respeito a ato válido acidentalmente revogável, ou a ato inválido relativo, cessa o tempo hábil de a exercer, no instante em que a eficácia se opera. Quid? Quanto ao ato nulo? Não é preciso dizer que a trajetória do ato nulo é curiosa. Se não o revogam, ou se, como os privatistas preferem, não vai a juízo a sua apreciação, pode êle permanecer por todo o tempo a produzir efeitos efetivamente parecidos com os efeitos jurídicos, i.é, efeitos corados. Por isto, não deixará jamais de ser nulo, salvo se, militando circunstância especialíssima que a reclame, uma conversão à base do "magis valeat quam pereat", de Juliano (De rebus dubiis) lhe sane o vício originário. Mas a conversão, nesta base, é de rara aplicação e só se justifica, se exercitada em atendimento de uma necessidado 
conexa com a alta utilidade, como é o caso do "propter eorum utilitatem eos qui apud egerunt", de que fala Ulpiano, no "De officio praetorum". Se, porém, o ato administrativo é nulo e só depois de se arrastar, como tal, é atingido pela revogação, está esta, sempre, em seu tempo hábil, pois que "quod initio vitiosum est nec tractu temporis convalescere potest".

\section{Observações finais}

14 - Da resenha de idéias aqui feitas, um ensinamento, de ordem geral, se tira, sem dúvida. E é êle indiscutivelmente prestativo para quem pode "revogar" e também supõe que pode "anular".

"Anular" e "revogar" não se confundem. "Anular" é fazer nulo o que ainda não o é; não é transformar em "nada" ("nulla, "nullum" — de "non ulla" e "non ullum") o que, sendo "algo", não é precisamente o que a lei desejaria que fôsse. Tão comezinhas idéias, conquanto pareçam do domínio dos mestres e dos que se dizem acostados a êles, não são tão familiares quanto, vez por outra, afirmam ser.

O discernimento, que procurámos sugerir nesta rápida tarefa, mostra, só por só, que dificuldades de monta cumpre ao juiz e ao intérprete em gênero desfazer. Oxalá, na emprêsa, tenhamos sido claros, para que alimentemos a ilusão de que fomos úteis. E' o que, data venia, ousamos declarar que é de nossos votos, desejo e intuito. 